\title{
New U-Pb SHRIMP zircon ages for pre-variscan orthogneisses from Portugal and their bearing on the evolution of the Ossa-Morena Tectonic Zone
}

\author{
UMBERTO G. CORDANI ${ }^{1}$, ALLEN P. NUTMAN ${ }^{2}$, ANTONIO S. ANDRADE ${ }^{3}$ \\ JOSÉ F. SANTOS ${ }^{3}$, MARIA DO ROSÁRIO AZEVEDO ${ }^{3}$, MARIA HELENA MENDES ${ }^{3}$ \\ and MANUEL S. PINTO ${ }^{3}$ \\ ${ }^{1}$ Centro de Pesquisas Geocronológicas, Instituto de Geociências, Universidade de São Paulo \\ Rua do Lago, 562, Cidade Universitária, 05508-080 São Paulo, SP, Brasil \\ ${ }^{2}$ Research School of Earth Sciences, Australian National University, Canberra ACT 0200, Australia \\ ${ }^{3}$ Departamento de Geociências, Universidade de Aveiro, Campus de Santiago, 3810, Aveiro, Portugal \\ Manuscript received on February 14, 2005; accepted for publication on August 4, 2005; \\ contributed by UMBERTO G. CORDANI*
}

\begin{abstract}
New SHRIMP U-Pb zircon ages for the Portalegre and Alcáçovas orthogneisses document a complex preVariscan history for the Iberian basement in Portugal. The available geochemical and geochronological data for the Alcáçovas orthogneiss ( $c a .540 \mathrm{Ma}$ ) tend to favor its involvement in a Cadomian orogenic event. This is consistent with the development of an active continental margin setting at the end of the Proterozoic and supports a Gondwanan provenance for the Iberian crust. On the other hand, the Ordovician emplacement age obtained for the magmatic precursors of the Portalegre orthogneisses ( $497 \pm 10 \mathrm{Ma}$ ) provides additional evidence for the occurrence of rift-related magmatic activity during the Lower Paleozoic.
\end{abstract}

Key words: Cadomian orogeny, U-Pb geochronology, Iberian Massif, Ossa-Morena Zone.

\section{INTRODUCTION}

Comprehensive works about the geology of Iberia with compilations of isotope data, like those in Bea et al. 1987, Dallmeyer and Martínez-Garcia 1990 and Gibbons and Moreno 2002, clearly show a complex polymetamorphic evolution and an equally complex igneous history for the Variscan Fold Belt.

As for the age and nature of the pre-Variscan basement in the Peninsula, namely the extension and importance of the Cadomian and Lower Paleozoic events and the possible contribution of Archean, Paleo-, Meso- and Neoproterozoic materials to the

*Member, Academia Brasileira de Ciências Correspondence to: Prof. Umberto Cordani E-mail: ucordani@usp.br
Iberian crust, as deduced from isotope data, good progress has been made in such direction (ValverdeVaquero and Dunning 2000, Fernández-Suárez et al. 2002, just to cite a few) although intermingled with some controversy (e.g. Ábalos et al. 1993). The Pan African/Cadomian orogeny may have played a significant role in the geological evolution of such terrains and a Paleopaleozoic tectonomagmatic event is also indicated by structural, petrological and geochronological evidence (e.g. L.C. Gama Pereira, unpublished data, Quesada 1990, 1991, Ribeiro et al. 1990, Castro et al. 2002). The internal consistency of the data within each tectonostratigraphic unit of the Iberian Peninsula (Hesperian Massif, see Fig. 1) and the contrast between them provide evi- 
dence of the heterogeneity of the Variscan overprint imposed onto a previously existing basement.

In the Ossa-Morena Zone (OMZ), in SW Iberia, pre-Variscan plutonic activity is more evident than in the northern part of the Iberian Massif and its dating has been essential in unrevealing the Cadomian evolution of the Zone. Relevant data have been obtained mostly from rocks occurring in Spain (e.g. Blatrix and Burg 1981, Shäfer et al. 1988, 1999, Sánchez-Carretero et al. 1990, 1999, Sánchez Fabián 2000, Bandrés et al. 1999, 2000, Valladares et al. 2002, González Menéndez 2002 and compilation in Castro et al. 2002) whereas in Portugal existing data are scarce, predominantly from $\mathrm{Rb}-\mathrm{Sr}$ dating (compilations in Pinto 1984, Pinto et al. 1987), and frequently without proper geological control. Moreover, in several cases, data are relative to rocks occurring either in the strongly deformed border separating the OMZ from the Central Iberian Zone (CIZ), adding a few problems of interpretation (Abranches et al. 1979, Pinto 1980/81, Pereira and Macedo 1983, Ábalos and Eguíluz 1992, Ábalos et al. 1993, Noronha and Leterrier 2000, H.G.I.O. Chaminé, unpublished data, Oliveira et al. 2002a, b, Chaminé et al. 2003) or in the Aracena metamorphic belt, in the border separating the OMZ from the South Portuguese Zone (Díaz Azpiroz et al. 2002).

Priem et al. (1970, 1986) obtained Pre-Variscan ages by the whole-rock Rb-Sr isochron method for the deformed orthogneisses of Portalegre and Alcáçovas that occur in the Portuguese sector of the OMZ. Abranches et al. (1979) also obtained similar $\mathrm{Rb}-\mathrm{Sr}$ ages for the Portalegre unit. All these granitoids yielded Ordovician apparent ages that shall be compared with new data obtained by other methods, as well as with available data for other rock units.

In the present work several zircon crystals from two samples collected from the Portalegre and the Alcáçovas granitoids were analyzed and geochemical data for these rocks, including REE data, are also presented and discussed as a contribution to the nature and chronology of the major tectonothermal events that affected the Portuguese sector of the OMZ.
The new U-Pb zircon ages, although being regarded as a reconnaissance tool in the sense used by Kalsbeek and Nutman (1996), are considered of importance not only because they are the first $\mathrm{U}-\mathrm{Pb}$ zircon ages (SHRIMP method) for the pre-Variscan granitoids of these areas of the OMZ, but also because such type of data is not common in the whole Zone (see Castro et al. 2002).

\section{GEOTECTONIC SETTING}

The Iberian Massif constitutes the SW extension of the European Hercynides and includes a nearly complete cross section through the Variscan orogen. It is bounded to the north and west by the Bay of Biscay and the Atlantic Ocean, at the southeast by the Guadalquivir fault and it is covered, in the east and in the west, by Mesozoic and Tertiary platform sediments.

Differences in stratigraphic, structural, metamorphic and magmatic style have led Lotze (1945) and Julivert et al. (1974) to subdivide the Iberian Massif into five major zones (Fig. 1). These are from NE to SW: the Cantabrian, West Asturian Leonese, Central Iberian, Ossa Morena and South Portuguese Zones.

The OMZ is one of the internal zones of the Iberian Variscan Fold Belt and comprises Precambrian and Paleozoic rocks variably affected by Variscan tectono-metamorphic events (Chacón et al. 1983). The Variscan deformation is responsible for most of the penetrative structures observed in the OMZ (Castro et al. 2002). Such NW-SE trending structures vary in style and intensity across the strike and tend to be progressively younger from SW to NE according to Apalategui et al. (1990).

The regional metamorphic evolution is complex. Mineral assemblages do not generally exceed low-grade but can reach, in places, high-grade granulite - facies, mostly associated with thermal doming. (Quesada and Munhá 1990, Fonseca et al. 1999). The magmatic activity related to the Variscan orogenic cycle is represented by volcanic and by plutonic rocks with ages clustered in the interval 


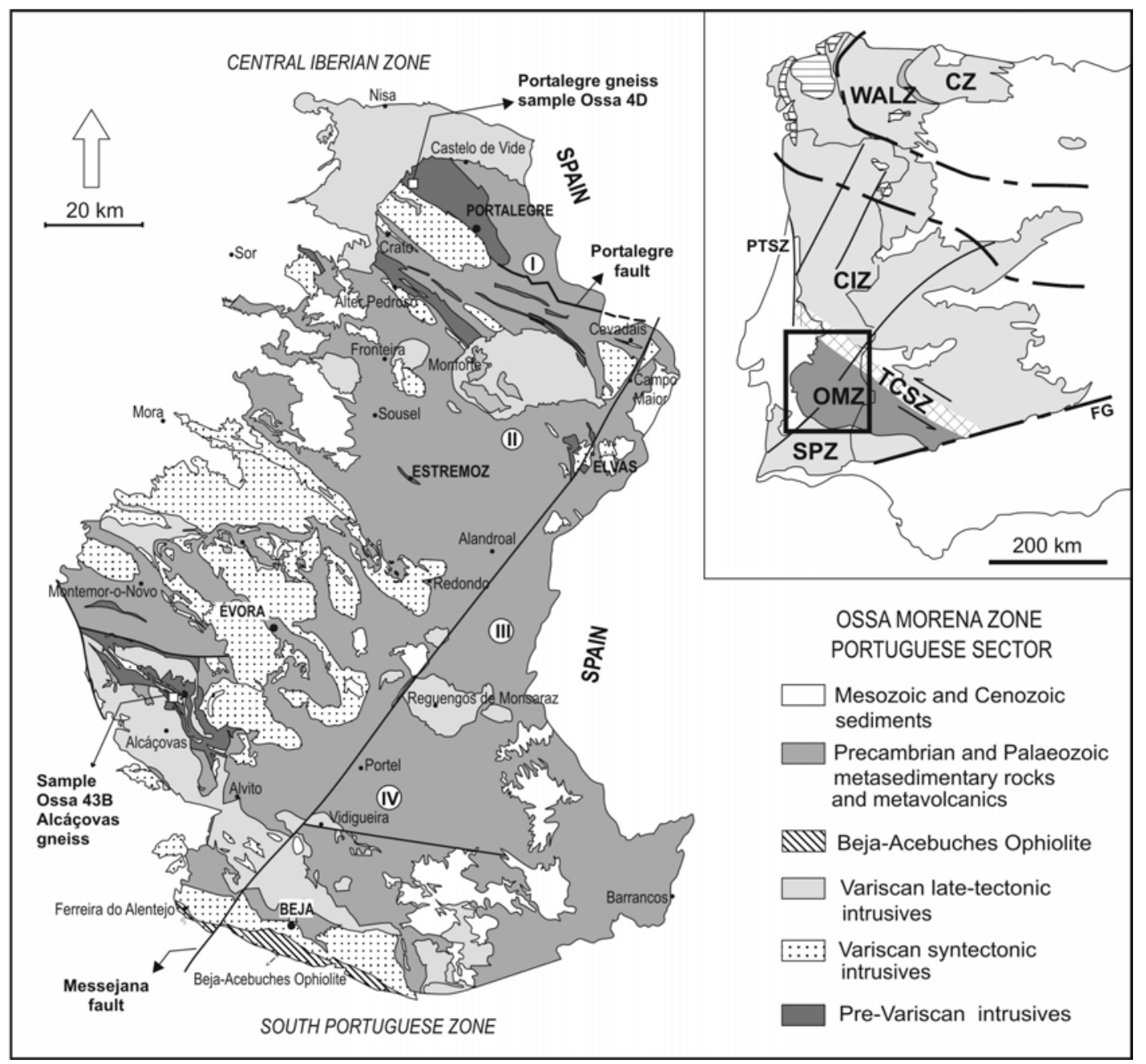

Fig. 1 - Geological sketch map of the Portuguese sector of the Ossa-Morena Zone (after Oliveira et al. 1992), showing the location of the studied samples. Box: Subdivision of the Iberian (or Hesperian Massif) after Lotze 1945 and Julivert et al. 1974. CZ - Cantabrian Zone; WALZ - West Asturian Leonese Zone; CIZ - Central Iberian Zone; OMZ - Ossa-Morena Zone; SPZ - South Portuguese Zone; PTSZ - Porto - Tomar Shear Zone; TCSZ - Tomar - Córdoba Shear Zone; FG - Guadalquivir Fault.

345-280 Ma (e.g. Pinto 1984, L.C. Gama Pereira, unpublished data, Sánchez-Carretero et al. 1990, Dunning et al. 2002, González Menéndez 2002).

It is now generally accepted that the OMZ was affected by an older tectonic cycle during Proterozoic times (L.C. Gama Pereira, unpublished data, L. Eguíluz, unpublished data), involving a rifting episode over a continental basement, followed by the opening of a small ocean basin, subduction and collision (Apalategui et al. 1990, Ribeiro et al. 1990). However, the intense Variscan reactivation, together with the scarcity of unequivocal petrological and geochronological data, does not allow a full reconstruction of the pre-Variscan evolution of the OMZ. Nevertheless, a few dates of both mafic and felsic igneous rocks support the existence of Pan-African/ Cadomian magmatic activity in the OMZ at 630$580 \mathrm{Ma}$ (H-J. Schäfer, unpublished data, A. Ochsner, unpublished data, Castro et al. 2002).

According to Ribeiro et al. (1990) and Apalategui et al. (1990), the OMZ underwent rifting and a passive margin type evolution during most of the Lower Paleozoic. The rifting process is indicated by the occurrence of Lower Cambrian tholeiites, 
Middle Cambrian transitional-alkaline associations and Ordovician-Silurian intraplate alkaline volcanic rocks, thought to represent off-rift magmatism (Mata and Munhá 1985, 1990). An extensional intracontinental regime has been also suggested by the presence of a number of alkaline and peralkaline plutonic rocks yielding ages around $480 \mathrm{Ma}$ (Priem et al. 1970, Abranches et al. 1979, Lancelot and Allegret 1982, Garcia Casquero et al. 1985, Galindo et al. 1990, A. Ochsner, unpublished data, SánchezCarretero et al. 1990, 1999).

Although the available stratigraphic and structural evidence supports the occurrence of Pan-African/Cadomian deformation and metamorphism in the OMZ, the ages of the Precambrian tectonometamorphic and magmatic events are not precisely constrained in the Portuguese sector of the OMZ due to the lack of reliable geochronological data. In contrast, there are already several radiometric ages confirming the influence of this orogenic cycle in the Spanish extension of the OMZ (Bellon et al. 1979, Blatrix and Burg 1981, Dallmeyer and Quesada 1992, A. Oschner, unpublished data, B. Ordoñez-Casado, unpublished data).

\section{PORTALEGRE ORTHOGNEISS}

The analyzed Portalegre orthogneiss occurs as part of a relatively large, elongate and complex massif that includes the city of Portalegre. The massif is crosscut by a NW-SE high-angle reverse fault known as the Portalegre fault and lies largely within a major NW-SE shear zone of the Iberian Variscides: the Tomar - Córdoba sinistral shear zone (Burg et al. 1981, TCSZ in figure 1). To the north of the fault, the massif is composed of a syenogranite orthogneiss, generally coarse-grained, that may grade, in places, into more intensely sheared, fine-grained varieties (Wilkinson et al. 1984). To the south of the Portalegre fault, it consists of a weakly foliated monzogranite (Carrascal granite) with large dioritic enclaves (Pereira and Silva 2002).

Based on field evidence Teixeira (1976) considered the Portalegre massif to be ante-Ordovician/ post Complexo Xisto-Grauváquico (Late Proterozoic). In the more recently published geological map of Portugal at the 1:500,000 scale (Oliveira et al. 1992), the syenogranite orthogneiss was included in the group of the pre-Hercynian orthogneisses, which is consistent with field and structural evidence (Burg et al. 1981) and with the available geochronological data. The monzogranite is referred to the syntectonic Variscan granitoids in that map, but is considered to be a Lower Paleozoic granitoid by Pereira and Silva (2002).

As already mentioned, Priem et al. (1970) dated some of the pre-Variscan intrusions of the Portalegre region by the whole-rock $\mathrm{Rb}-\mathrm{Sr}$ isochron method. They plotted in the same $\mathrm{Rb}-\mathrm{Sr}$ isochron diagram eight samples collected from three distinct orthogneissic bodies (Alter Pedroso, Cevadais and Portalegre) with highly variable compositions (sodalite syenites; syenites; peralkaline syenites and granites; syenogranites). Some of the samples had very high $\mathrm{Rb} / \mathrm{Sr}$ ratios. The best-fit line encompassing six of the analytical points yielded an Ordovician age of $482 \pm 12 \mathrm{Ma}$ (recalculated for $\lambda \mathrm{Rb}=$ $1.42 \times 10^{-11} \mathrm{x} \mathrm{a}^{-1}$ ) and a very imprecise ${ }^{87} \mathrm{Sr} /{ }^{86} \mathrm{Sr}$ initial ratio $(0.703 \pm 0.003)$. This age was interpreted as reflecting the time of emplacement of the Portalegre area intrusions.

Abranches et al. (1979) using four samples of the Portalegre orthogneisses obtained $440 \pm 6 \mathrm{Ma}$ for the apparent "age" of the massif $\left({ }^{87} \mathrm{Sr} /{ }^{86} \mathrm{Sr}\right.$ initial ratio $=0.70752 \pm 0.00026(1 \sigma) ; \operatorname{MSWD}=3.05)$. Inclusion of data relative to one of the samples from Priem et al. (1970) would not change the "age", but the MSWD would be increased.

The Lower Ordovician apparent age value was subsequently confirmed by Lancelot and Allegret (1982) with conventional U-Pb dating of zircons from the Alter Pedroso orthogneiss (482 $\pm 16 \mathrm{Ma})$. The zircon populations plotted close to the Concordia, and the age was interpreted as indicating the event of magmatic crystallization. Given the alkaline to peralkaline signature of the Alter Pedroso and Cevadais orthogneisses, the $482 \mathrm{Ma}$ age was taken to support the occurrence of a period of extension and 
thinning of the continental crust during Ordovician times (Sánchez-Carretero et al. 1990).

Although the presence of a number of alkaline and peralkaline plutonic rocks yielding ages around $480 \mathrm{Ma}$ suggests the existence of an extensional intracontinental regime during the Ordovician, the mineralogical and geochemical characteristics of the Portalegre orthogneisses do not match those of A-type granites from other parts of the world (e.g. Collins et al. 1982, Whalen et al. 1987).

The Portalegre syenogranite orthogneiss has quartz, K-feldspar (perthitic microcline), Na-plagioclase, biotite and muscovite as major mineral phases. Typical accessory minerals include apatite, zircon and opaque minerals. The rocks show abundant microstructural evidence of having undergone solid-state deformation after the emplacement of their igneous precursors, including: presence of a gneissic foliation; development of fine-grained mylonitic zones in the groundmass; fracture, bending and marginal recrystallization of microcline and plagioclase porphyroclasts; recovery and recrystallization of quartz to finer-grained aggregates; elongate shape of the quartz aggregates; occurrence of lenses of newly formed biotite, sphene and opaques.

Chemical analyses of two samples from the Portalegre syenogranite orthogneiss (Ossa 4D and Ossa 5c) are presented in Table I. From a geochemical point of view, these rocks are characterized by high $\mathrm{SiO}_{2}$ values $\left(\mathrm{SiO}_{2}=74-76 \%\right)$, weakly to strongly peraluminous compositions (ASI $=1.00$ 1.29), low HFSE (e.g. $\mathrm{Zr}<105 \mathrm{ppm}, \mathrm{Nb}=12-17$ ppm) and extremely low REE contents $(\Sigma$ REE $=$ 40-90 ppm) (Fig. 2). They exhibit nearly flat REE patterns $\left(\mathrm{La}_{\mathrm{N}} / \mathrm{Lu}_{\mathrm{N}}=1.5-3.7\right)$ and a well defined negative $\mathrm{Eu}$ anomaly $\left(\mathrm{Eu} / \mathrm{Eu}^{*}<0.4\right)$ (Fig. 3).

Given the highly evolved character of the Portalegre orthogneiss it is possible that its igneous protolith would correspond to an extremely fractionated and/or crustally contaminated A-type granitoid rock, formed during a continental rifting episode. However, an orogenic scenario at the time of granite formation cannot be definitely ruled out. In fact, the occurrence of subduction-related magmatism of
Upper Cambrian-Lower Ordovician age in the OMZ has also been invoked by Mata et al. (1999).

\section{ALCÁÇOVAS ORTHOGNEISS}

The Alcáçovas orthogneiss, firstly described by Andrade (1974), crops out about $5 \mathrm{~km} \mathrm{~N}$ of the village of Alcáçovas in the Évora area (Fig. 1). These rocks are part of a large complex that was included in the group of pre-Hercynian orthogneisses in the geological map of Portugal (Oliveira et al. 1992).

The Alcáçovas orthogneiss is a deformed finegrained granitoid showing a N-S trending tectonic foliation, subsequently affected by NW-SE folding related to the Variscan orogenic cycle (Andrade 1974). At the present level of exposure, this unit is intruded by Variscan porphyries and dolerite dykes. The porphyry dykes belong to a large belt about $105 \mathrm{~km}$ long and up to $15 \mathrm{~km}$ wide that extends along the southwestern end of the OMZ. They have dacite to rhyodacite compositions and exhibit a distinctive calc-alkaline signature (Santos et al. 1987). For a few samples of them, a Rb-Sr whole-rock age of $319 \pm 5$ Ma was obtained by Priem et al. (1986). The same authors also obtained a five point $\mathrm{Rb}-\mathrm{Sr}$ whole rock "isochron" of $456 \pm 23 \mathrm{Ma}$ for the Alcáçovas orthogneisses. However, four of their analytical points plot very close in the ${ }^{87} \mathrm{Sr} /{ }^{86} \mathrm{Sr}$ vs. ${ }^{87} \mathrm{Rb} /{ }^{86} \mathrm{Sr}$ diagram defining, in practice, a two-point isochron. Moreover, the corresponding ${ }^{87} \mathrm{Sr} /{ }^{86} \mathrm{Sr}$ initial ratio $(0.710 \pm 0.001)$ is much higher than expected from petrological and geochemical data (Table I). As such, it is possible that the $456 \pm 23 \mathrm{Ma}$ "isochron" does not reflect the real intrusion age of the Alcáçovas orthogneisses.

Based on studies of Boogaard (1972, 1983), a ca. $375 \mathrm{Ma}$ age for the Hercynian deformation of the Alcáçovas granite intrusion was assumed by Priem et al. (1986). These authors also reported K-Ar ages of 333-339 Ma for biotites of the Alcáçovas orthogneisses, concluding that these ages could date the end of the Variscan metamorphism.

The main facies is a monzogranite orthogneiss consisting of quartz, variably sericitized plagio- 
TABLE I

Major and trace element composition of the Portalegre and Alcáçovas orthogneisses.

\begin{tabular}{|c|c|c|c|c|c|c|}
\hline \multirow[b]{2}{*}{ Sample } & \multicolumn{4}{|c|}{ Portalegre orthogneiss } & \multicolumn{2}{|c|}{ Alcáçovas orthogneiss } \\
\hline & Ossa 4D ${ }^{(1)}$ & Ossa 5C ${ }^{(1)}$ & PG $2^{(2)}$ & PG $9^{(2)}$ & Ossa 43B ${ }^{(1)}$ & $1^{(3)}$ \\
\hline $\mathrm{SiO}_{2}$ & 76.27 & 76.46 & 73.9 & 75.1 & 72.98 & 71.96 \\
\hline $\mathrm{TiO}_{2}$ & 0.13 & 0.06 & 0.16 & 0.06 & 0.32 & 0.46 \\
\hline $\mathrm{Al}_{2} \mathrm{O}_{3}$ & 12.95 & 12.97 & 13.76 & 13.16 & 14.37 & 14.08 \\
\hline $\mathrm{Fe}_{2} \mathrm{O}_{3} \mathrm{t}$ & 1.37 & 1.41 & 1.43 & 1.57 & 2.37 & 2.86 \\
\hline $\mathrm{MnO}$ & 0.02 & 0.01 & 0.02 & 0.03 & 0.04 & 0.03 \\
\hline $\mathrm{MgO}$ & 0.16 & 0.11 & 0.18 & 0.22 & 0.39 & - \\
\hline $\mathrm{CaO}$ & 0.55 & 0.18 & 0.79 & 0.32 & 1.42 & 1.36 \\
\hline $\mathrm{Na}_{2} \mathrm{O}$ & 3.25 & 2.81 & 3.95 & 3.01 & 3.77 & 3.96 \\
\hline $\mathrm{K}_{2} \mathrm{O}$ & 4.83 & 4.69 & 5.37 & 5.22 & 4.27 & 4.88 \\
\hline $\mathrm{P}_{2} \mathrm{O}_{5}$ & 0.15 & 0.20 & 0.17 & 0.22 & 0.06 & 0.06 \\
\hline LOI & 0.76 & 1.13 & nd & nd & 0.24 & 0.31 \\
\hline Total & 100.41 & 100.02 & 99.73 & 98.91 & 100.23 & 99.96 \\
\hline $\mathrm{Rb}$ & 192 & 239 & 226 & 318 & 89 & nd \\
\hline $\mathrm{Ba}$ & 269 & 21 & 263 & 142 & 1070 & nd \\
\hline Th & 8.00 & 6.00 & 9.3 & 6.8 & 9.24 & nd \\
\hline $\mathrm{Nb}$ & 12.6 & 12.0 & 16 & 17 & 8.6 & nd \\
\hline $\mathrm{Ta}$ & 1.2 & 1.2 & 1.2 & 1.5 & 0.6 & nd \\
\hline $\mathrm{Sr}$ & 27 & 10 & 31 & 12 & 86 & nd \\
\hline $\mathrm{Zr}$ & 97 & 57 & 104 & 68 & 250 & nd \\
\hline $\mathrm{Hf}$ & 3.4 & 2.1 & 3.5 & 2.7 & 6.8 & nd \\
\hline $\mathrm{Y}$ & 34.1 & 20.0 & 33 & 16 & 32.2 & nd \\
\hline $\mathrm{La}$ & 14.4 & 4.92 & 13 & 5.5 & 39.2 & nd \\
\hline $\mathrm{Ce}$ & 32.3 & 13.2 & 29 & 13 & 77.0 & nd \\
\hline $\operatorname{Pr}$ & 3.83 & 1.67 & nd & nd & 8.60 & nd \\
\hline $\mathrm{Nd}$ & 14.7 & 6.14 & 16 & 8.2 & 33.9 & nd \\
\hline $\mathrm{Sm}$ & 4.12 & 2.21 & 4.3 & 2.1 & 6.76 & nd \\
\hline $\mathrm{Eu}$ & 0.280 & 0.019 & 0.32 & 0.05 & 0.640 & nd \\
\hline $\mathrm{Gd}$ & 4.34 & 2.19 & nd & nd & 6.80 & nd \\
\hline $\mathrm{Tb}$ & 0.96 & 0.59 & 0.88 & 0.47 & 1.07 & nd \\
\hline Dy & 5.95 & 3.78 & nd & nd & 5.90 & nd \\
\hline Ho & 1.13 & 0.69 & nd & nd & 1.16 & nd \\
\hline $\mathrm{Er}$ & 3.24 & 2.13 & nd & nd & 3.28 & nd \\
\hline $\mathrm{Tm}$ & 0.526 & 0.378 & nd & nd & 0.504 & nd \\
\hline $\mathrm{Yb}$ & 3.26 & 2.60 & 2.2 & 1.3 & 3.21 & nd \\
\hline $\mathrm{Lu}$ & 0.423 & 0.352 & 0.43 & 0.22 & 0.479 & nd \\
\hline
\end{tabular}

(1) data obtained by ICP-AES and ICP-MS in the Actlabs for this work; (2) data from Wilkinson et al. (1984); (3) data from Andrade (1974); nd: not determined. 


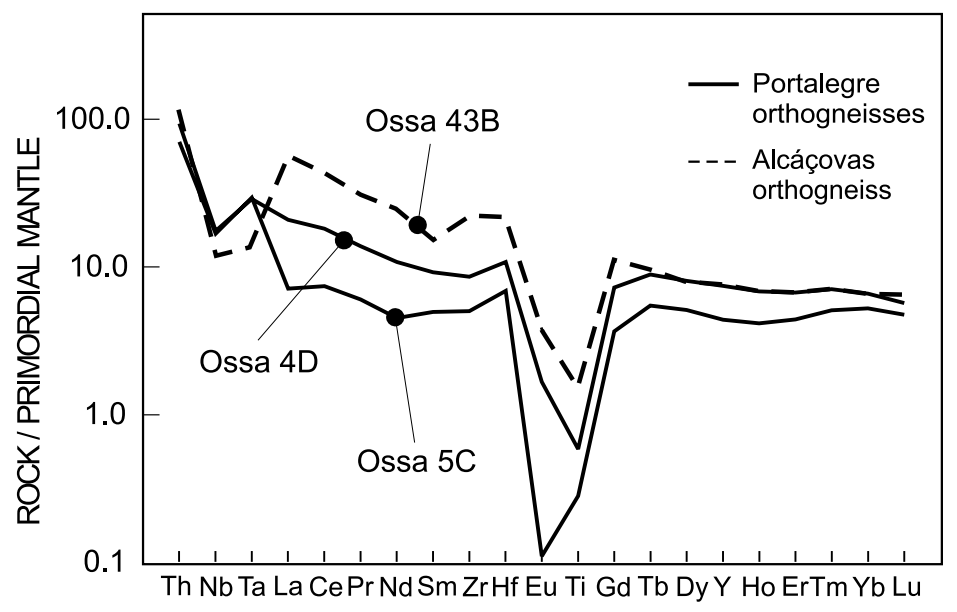

Fig. 2 - Primitive mantle normalized multi-element diagram for the Portalegre and Alcáçovas orthogneisses. Normalization constants after Sun and McDonough (1989).

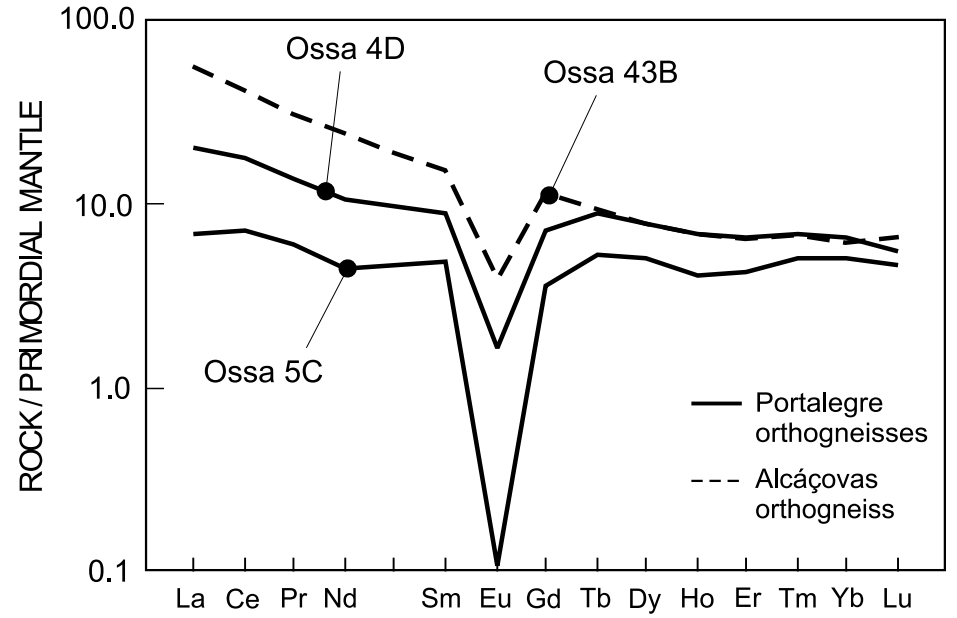

Fig. 3 - REE primitive mantle normalized patterns for the Portalegre and Alcáçovas orthogneisses. Normalization constants after Sun and McDonough (1989).

clase (oligoclase), K-feldspar (microcline), biotite and amphibole (hornblende to hornblende-actinolite). Sphene, apatite and zircon are common accessory minerals. At thin section scale, the foliation is defined by the parallel alignment of biotite and amphibole. As a result of heterogeneous deformation and recrystallization of quartz and feldspar, the texture varies from mylonitic to granoblastic. The mylonitic domains are generally inequigranular and contain strained older grains of feldspar and quartz that appear to correspond to relict igneous crystals. They are distinguished from those of the surrounding matrix by their larger size and, in the case of the K-feldspars, by the presence of rounded or subhedral inclusions of quartz and plagioclase. Typical granoblastic textures also occur and consist of aggregates of equant, xenoblastic, polygonal- or lobate-shaped quartz and feldspar grains.

Geochemically, the Alcáçovas monzogranite orthogneiss (sample Ossa 43b) is characterized by $\mathrm{SiO}_{2}$ values of $c a .73 \%$, ASI $=1.07$, relatively high $\mathrm{CaO}$ contents $(\mathrm{CaO}=1.42 \%)$, moderately fraction- 
ated REE patterns $\left(\mathrm{La}_{\mathrm{N}} / \mathrm{Lu}_{\mathrm{N}}=8.8\right)$ and negative $\mathrm{Eu}$ and $\mathrm{Nb}$ anomalies $\left(\mathrm{Eu} / \mathrm{Eu}^{*}=0.29 ; \mathrm{Th}_{\mathrm{N}} / \mathrm{Nb}_{\mathrm{N}}=9.0\right.$; $\mathrm{La}_{\mathrm{N}} / \mathrm{Nb}_{\mathrm{N}}=4.7$ ) (see Table I; Fig. 2 and Fig. 3). The chemical signature of the Alcáçovas orthogneisses strongly suggests a derivation from calc-alkaline magmas typical of orogenic tectonic settings. In our view, an A-type or S-type provenance for their igneous protoliths can be precluded.

\section{SHRIMP U/Pb GEOCHRONOLOGY}

\section{SAMPLING AND ANALYSES}

The sample of the Portalegre orthogneiss (Ossa 4D) was collected at the Maceira quarry, near the Alagoa village, about $15 \mathrm{~km} \mathrm{NW}$ of Portalegre (Fig. 1). Sample Ossa 43B belongs to the Alcáçovas orthogneiss and was collected near $\mathrm{km} 549$ of the EN 2 road (Fig. 1). The location of sample Ossa 43B is the same of the samples used for Rb-Sr whole-rock dating by Priem et al. (1986).

Sample preparation was carried out at the University of Aveiro. For each sample, $c a$. 5-10 kg fresh material was prepared by crushing, grinding and sieving. Zircon concentrates were obtained using conventional heavy liquid techniques and a Frantz magnetic separator. Final purification of the mineral population was achieved by handpicking under a binocular microscope.

Together with chips of standard zircon, the zircon grains were mounted in epoxy resin discs and polished with $\mathrm{Pb}$-free materials. The epoxy was coated with a thin conducting Au film. Assessment of grains and choice of sites for analysis were based on transmitted/reflected light microscopy and cathodoluminescence (CL) imaging. The analyses were performed on a limited number of zircon grains and only a few age determinations were obtained, the analytical results being summarized in Table II.

The isotopic measurements were carried out using the SHRIMP I microprobe instrument at the Australian National University (ANU) in Canberra. For the SHRIMP analyses, the samples were stroke with a mass filtered $\mathrm{O}^{2-}$ primary ion beam using a $c a .30 \mu \mathrm{m}$ diameter spot. The mass resolution measured at $1 \%$ peak height was between 5,500 and 6,000. Details of the analytical procedures can be found in Stern (1998) and in Williams (1998).

The ${ }^{206} \mathrm{~Pb} /{ }^{238} \mathrm{U}$ ratios have an error component (typically 1.5 to $2.0 \%$ ) from calibration of the measurements using standard zircons SL13 (single crystal) and AS57 (multicrystal). All quoted errors are $1 \sigma$, and take into account the non-linear fluctuations in ion counting rates beyond that expected from counting statistics (e.g. Stern 1998). The decay constants and present-day ${ }^{238} \mathrm{U} /{ }^{235} \mathrm{U}$ value used to calculate dates for Phanerozoic zircons are given by Steiger and Jager (1977). The final ages were derived from the ${ }^{206} \mathrm{~Pb} /{ }^{238} \mathrm{U}$ ratios, after correction for common $\mathrm{Pb}$ by the measured ${ }^{207} \mathrm{~Pb}$ (Compston et al. 1984). With only two exceptions (sample Ossa$43 \mathrm{~B}$, spots 1.1 and 1.3 , see Table II), the analyzed zircon crystals showed little or even undetectable common $\mathrm{Pb}$. This age calculation procedure was not applied to the Archean zircon crystal of the Alcáçovas orthogneiss (Ossa 43B - spot 2.1), whose date is the ${ }^{207} \mathrm{~Pb} /{ }^{206} \mathrm{~Pb}$ age, after correction using the measured ${ }^{206} \mathrm{~Pb} /{ }^{204} \mathrm{~Pb}$ ratio.

\section{RESULTS AND DISCUSSION}

Representative U-Pb Tera - Wasserburg concordia plots for samples Ossa 4D and 43B are shown in Fig. 4 and in Fig. 5, respectively.

\section{PortAlEGRE ORTHOGNEISSES}

Most of the zircon crystals of sample Ossa 4D are fragments of pale yellow, euhedral prisms. They may also occur as longer prisms with pyramidal terminations, and some smaller equant grains were also recognized. In the CL images, internal structures are simple and neither cores nor overgrowths were observed. With the exception of spot 2.1 ( $\mathrm{U}=$ $682 \mathrm{ppm})$, the uranium contents are generally low (100-360 ppm).

Five of the analyzed spots, located in the least disturbed portions of the larger prismatic grains, plot as nearly concordant points in the Tera-Wasserburg diagram and yield an average ${ }^{206} \mathrm{~Pb} /{ }^{238} \mathrm{U}$ age of $497 \pm 10 \mathrm{Ma}(2 \sigma, \mathrm{MSWD}=0.89)$ (Fig. 4). Four of 
TABLE II

SHRIMP U-Pb zircon analyses for samples Ossa 4D (Portalegre) and Ossa 43B (Alcáçovas).

\begin{tabular}{|c|c|c|c|c|c|c|c|}
\hline $\begin{array}{c}\text { Sample } \\
\text { number } \\
\text { (1) }\end{array}$ & $\begin{array}{c}\text { Site } \\
\text { description } \\
(2)\end{array}$ & $\begin{array}{c}\mathrm{U} \\
\mathrm{ppm}\end{array}$ & $\begin{array}{l}\text { Th } \\
\text { ppm }\end{array}$ & $\begin{array}{l}{ }^{206} \mathrm{~Pb} / \\
{ }^{204} \mathrm{~Pb}\end{array}$ & $\begin{array}{l}\text { Uncorrected } \\
{ }^{238} \mathrm{U} /{ }^{206} \mathrm{~Pb}\end{array}$ & $\begin{array}{l}\text { Uncorrected } \\
{ }^{207} \mathrm{~Pb} /{ }^{206} \mathrm{~Pb}\end{array}$ & $\begin{array}{c}{ }^{238} \mathrm{U} / \\
{ }^{206} \mathrm{~Pb}_{\text {age, }} \mathrm{Ma} \\
(3)\end{array}$ \\
\hline Ossa & $4 \mathrm{D}$ & & & & & & \\
\hline 1.1 & $\mathrm{P}, \mathrm{osc}$ & 222 & 74 & $1.15 \times 10^{-4}$ & $12.4 \pm 0.31$ & $0.0558 \pm 0.0011$ & $502.5 \pm 12.3$ \\
\hline 2.1 & $\mathrm{P}, \mathrm{osc}, \mathrm{fr}$ & 682 & 59 & $0.17 \times 10^{-4}$ & $12.0 \pm 0.34$ & $0.0559 \pm 0.0010$ & $518.8 \pm 14.0$ \\
\hline 3.1 & St, sm, hd & 363 & 71 & $6.57 \times 10^{-4}$ & $12.4 \pm 0.31$ & $0.0840 \pm 0.0021$ & $486.7 \pm 11.7$ \\
\hline 4.1 & $\mathrm{P}, \mathrm{osc}, \mathrm{fr}$ & 174 & 248 & $0.72 \times 10^{-4}$ & $12.8 \pm 0.28$ & $0.0564 \pm 0.0010$ & $486.9 \pm 10.4$ \\
\hline 5.1 & $\mathrm{P}$, osc, fr & 109 & 105 & $1.40 \times 10^{-4}$ & $12.4 \pm 0.32$ & $0.0557 \pm 0.0013$ & $500.6 \pm 12.5$ \\
\hline 6.1 & $\mathrm{P}, \mathrm{fr}$ & 226 & 34 & $2.38 \times 10^{-4}$ & $12.5 \pm 0.29$ & $0.0585 \pm 0.0013$ & $497.9 \pm 11.2$ \\
\hline Ossa & $43 \mathrm{~B}$ & & & & & & \\
\hline 1.1 & $\mathrm{P}, \mathrm{tw}, \mathrm{osc}$ & 141 & 94 & $49.41 \times 10^{-4}$ & $12.06 \pm 0.33$ & $0.1310 \pm 0.0027$ & $469.3 \pm 12.6$ \\
\hline 1.2 & $\mathrm{P}, \mathrm{tw}, \mathrm{osc}$ & 122 & 75 & $2.39 \times 10^{-4}$ & $11.70 \pm 0.27$ & $0.0578 \pm 0.0015$ & $529.6 \pm 11.9$ \\
\hline 1.3 & $\mathrm{P}, \mathrm{tw}, \mathrm{osc}$ & 378 & 355 & $18.65 \times 10^{-4}$ & $12.49 \pm 0.27$ & $0.0868 \pm 0.0009$ & $480.0 \pm 9.9$ \\
\hline 2.1 & $\mathrm{Eq}, \mathrm{hb}, \mathrm{co}$ & 152 & 101 & $0.18 \times 10^{-4}$ & $2.07 \pm 0.09$ & $0.1701 \pm 0.0073$ & $2556 \pm 74 * *$ \\
\hline 3.1 & St, hc & 657 & 145 & Below $1 \times 10^{-5}$ & $13.31 \pm 0.29$ & $0.0571 \pm 0.0006$ & $468.3 \pm 10.0$ \\
\hline 4.1 & $\mathrm{Eq}, \mathrm{rd}$ & 864 & 154 & Below $1 \times 10^{-5}$ & $11.02 \pm 0.27$ & $0.0575 \pm 0.0004$ & $561.2 \pm 13.0$ \\
\hline 5.1 & St, hd, rd & 204 & 48 & $0.78 \times 10^{-4}$ & $9.75 \pm 0.21$ & $0.0688 \pm 0.0010$ & $622.0 \pm 12.8$ \\
\hline 6.1 & $\mathrm{P}, \mathrm{osc}$ & 910 & 22 & Below $1 \times 10^{-5}$ & $17.62 \pm 0.35$ & $0.0538 \pm 0.0006$ & $358.1 \pm 7.0$ \\
\hline 6.2 & $\mathrm{P}$, osc & 854 & 30 & $0.24 \times 10^{-4}$ & $16.69 \pm 0.57$ & $0.0547 \pm 0.0013$ & $377.2 \pm 12.6$ \\
\hline 7.1 & St, osc & 403 & 354 & $0.41 \times 10^{-4}$ & $13.59 \pm 0.33$ & $0.0571 \pm 0.0007$ & $458.8 \pm 10.7$ \\
\hline 8.1 & St, hd, rd & 561 & 185 & Below $1 \times 10^{-5}$ & $11.59 \pm 0.25$ & $0.0585 \pm 0.0010$ & $534.1 \pm 11.1$ \\
\hline 9.1 & $\mathrm{P}$, osc & 464 & 381 & $0.37 \times 10-4$ & $11.50 \pm 0.23$ & $0.0584 \pm 0.0009$ & $537.9 \pm 10.6$ \\
\hline 10.1 & $\mathrm{P}, \mathrm{hb}, \mathrm{rim}$ & 324 & 20 & Below $1 \times 10^{-5}$ & $16.38 \pm 0.52$ & $0.0607 \pm 0.0025$ & $381.4 \pm 11.8$ \\
\hline 11.1 & $\mathrm{P}, \mathrm{hb}, \mathrm{rim}$ & 226 & 22 & Below $1 \times 10^{-5}$ & $16.12 \pm 0.72$ & $0.0652 \pm 0.0015$ & $385.2 \pm 16.8$ \\
\hline
\end{tabular}

(1) Analysis code: $\mathrm{x} . \mathrm{y}=$ grain. site number - Labels in bold used for date calculation ${ }^{(2)}$ Habit, CL imagery and site: $\mathrm{P}=$ long prism (aspect ratio $>2$ ); $\mathrm{St}=$ stubby prism (aspect ratio $<2$ ); $\mathrm{Eq}=$ equant, oval shape; $\mathrm{rd}$ = rounded; $\mathrm{sm}=$ small $(<100 \mu \mathrm{m}) ; \mathrm{tw}=$ twinned crystal; $\mathrm{fr}=$ fragment $; \mathrm{hb}=$ homogeneous bright; $\mathrm{hc}=$ homogeneous clear; hd = homogeneous dark; osc = fine scale oscillatory zoning; co = core; rim = rim (overgrowth). ${ }^{3}{ }^{238} \mathrm{U} /{ }^{206} \mathrm{~Pb}$ age, after correction for common $\mathrm{Pb}$ by 207 method (assumes concordance) $* * 207 \mathrm{~Pb} /{ }^{206} \mathrm{~Pb}$ date for grain 2.1 , (99\% concordant), after correction using measured ${ }^{206} \mathrm{~Pb} /{ }^{204} \mathrm{~Pb}$. All quoted errors are 1 sigma.

the points plot just below Concordia, most probably due to a slight overestimation of the day's standard calibration. One small, dark brown, equant crystal is highly discordant (spot 3.1) possibly due to the presence of inherited components. Since five of the six analyzed spots show concordant results, no additional data were obtained for sample Ossa 4D. The $497 \pm 10$ Ma age is in reasonable agreement with the ages reported by Priem et al. (1970) and by Lancelot and Allegret (1982).

A comparison between the zircon crystals of the Portalegre and those of the Alter Pedroso orthogneisses analyzed by Lancelot and Allegret (1982) shows that the latter are generally anhedral, equant and were possibly formed during a late crystallization stage of the parent alkaline magma. 


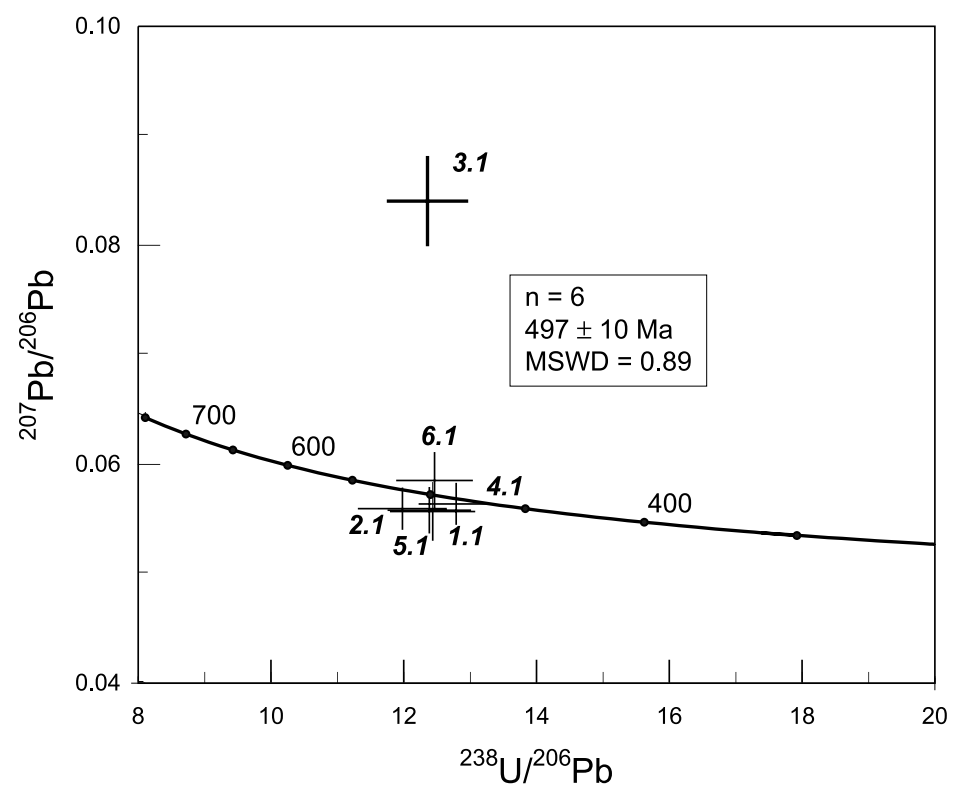

Fig. 4 - Tera-Wasserburg diagram for sample Ossa-4D (Portalegre orthogneiss).

Despite the marked differences in the petrological and geochemical signatures of the Portalegre syenogranites and the Alter Pedroso peralkaline rocks, the striking coincidence of ages between them suggests that the former could represent either highly differentiated or crustally contaminated A-type granitoids. If this is true, and following the widely accepted model of Ribeiro et al. (1990), the emplacement of the Portalegre syenogranites would have taken place during the extensional regime that is thought to have prevailed in the Lower Ordovician. It may be remembered that Early Paleozoic bimodal rift-related magmatism is widespread throughout much of the European Hercynides (e.g. Crowley et al. 2000).

\section{Alcáçovas Orthogneisses}

The zircon population of sample Ossa 43B is highly heterogeneous and consists of various grain subpopulations of different color and morphology and uranium content. For these reasons, the number of SHRIMP analyses obtained in the Alcáçovas orthogneisses is larger than that of the Portalegre orthogneisses. Many zircon crystals occur as long, yellow to pale brown, euhedral prisms with complex internal structures. Oscillatory zoning patterns, typical of magmatic derivation, are frequently seen in these grains. Other zircon sub-population is composed of short stubby prisms, usually darker in color, showing diffuse or structureless zoning. Small, dark crystals, possibly metamict, are also present. Distinct overgrowths of colorless zircon were observed in many of the analyzed grains. The CL-images indicate that a number of crystals have inherited cores. Uranium contents are highly variable and range between 100 and $900 \mathrm{ppm}$. The analytical points are plotted in the Tera-Wasserburg diagram of Fig. 5 and reveal a complex age pattern.

Analysis 2.1, not reported in the figure because of scale, comes from the core of a small prismatic crystal with low $\mathrm{U}$ content (152 ppm) yielding a late Archean/Paleoproterozoic age of $2540 \pm 40 \mathrm{Ma}$. Grain 5.1 corresponds to a stubby, homogeneous, prismatic crystal with a discordant ${ }^{207} \mathrm{~Pb} /{ }^{206} \mathrm{~Pb}$ apparent age at $c a$. $620 \mathrm{Ma}$, of obscure significance.

Concordant ages of $c a .540$ Ma were obtained in four zircon analyses $(4.1,8.1,9.1$ and 1.2 in Fig. 5). Their uranium contents vary greatly, between 120 and $870 \mathrm{ppm}$, and their morphologies are quite distinct: zircons grains 4.1 and 8.1 are small, 


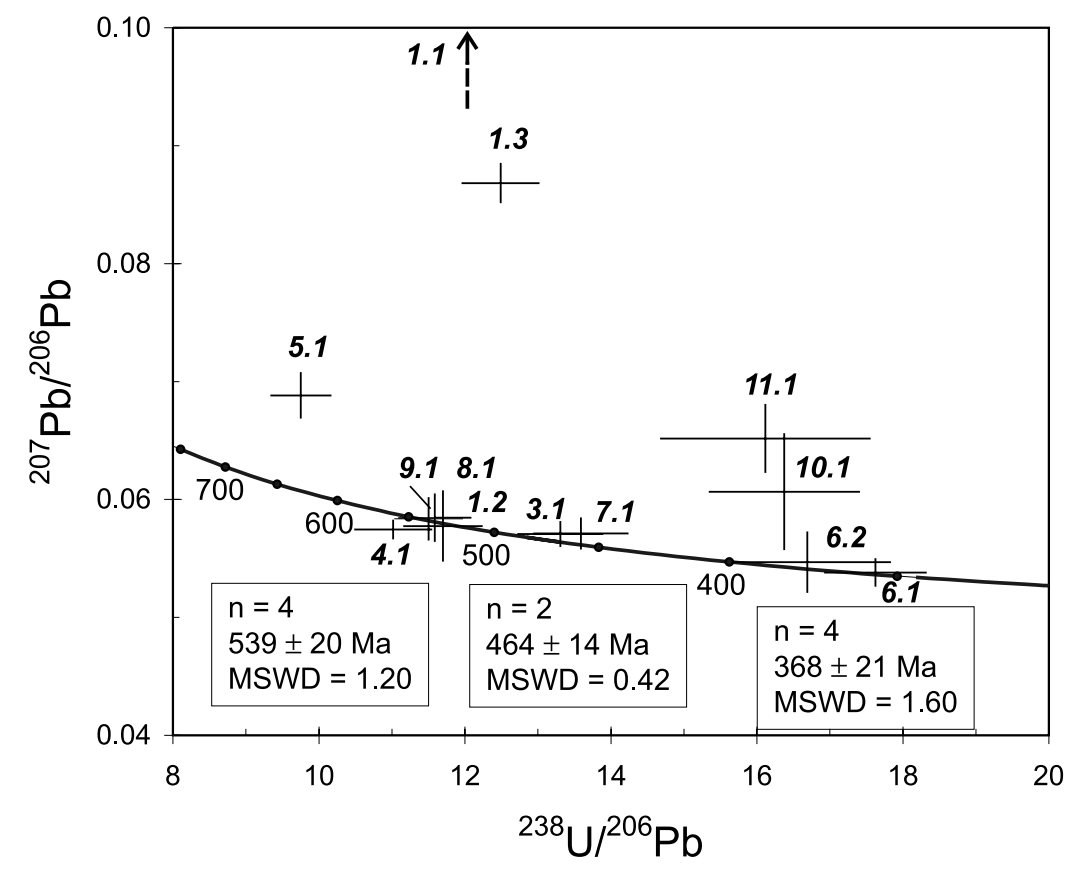

Fig. 5 - Tera-Wasserburg diagram for sample Ossa-43B (Alcáçovas orthogneiss).

homogeneous and somewhat rounded prisms, whilst zircon grain 9.1 corresponds to a long-prismatic, euhedral crystal with oscillatory zoning. Spot 1.2 is a low uranium domain within a large twinned heterogeneous crystal displaying oscillatory zoning. From this grain, two other analyses were obtained (spots 1.1 and 1.3), yielding different uranium contents and younger apparent ages of about 470-480 Ma. A simple age calculation for this age group (zircons 4.1, 8.1, 9.1 and 1.2) indicated an age of $539 \pm 20 \mathrm{Ma}$ $(2 \sigma, \operatorname{MSWD}=1.20)$.

Zircon crystals 3.1 and 7.1 yielded concordant ages of $c a .460$ Ma. Analysis 3.1 was targeted in a clear prism whereas zircon 7.1 is a small bipyramided prismatic crystal. A calculated age value for these two zircons indicates $464 \pm 14 \mathrm{Ma}$ (2 sigma, MSWD = 0.42). This age value is of the same order as the apparent ages for sites 1.1 and 1.3 already mentioned, although these were not included in the calculation because they present a high common lead correction.

Analyses 10.1 and 11.1 are from highly luminescent and structureless domains and may repre- sent areas of metamorphic reorganization of the zircon crystal lattice. Their apparent ages are close to $370 \mathrm{Ma}$, and similar ages were found in two different spots (6.1 and 6.2) of a single, euhedral, long prismatic crystal of zircon with oscillatory zoning and high uranium contents (854-910 ppm). The average age calculation for this age group $(6.1,6.2,10.1$ and 11.1) yielded $368 \pm 21 \mathrm{Ma}(2 \sigma, \mathrm{MSWD}=1.6)$. Zircon 9.1 showed a structureless apparently recrystallized domain and its analysis yielded a somewhat younger age whose significance is uncertain.

Despite the differences found in the new apparent age values, it is possible to place some time constraints on the evolution of the Alcáçovas orthogneisses.

The $c a .2 .5 \mathrm{Ga}$ age obtained in a clearly inherited zircon domain of crystal 2.1 is consistent with the involvement of Paleoproterozoic-Archean material in the genesis of late Precambrian and Paleozoic granitoids. Such a component is well-defined in detrital zircons from the OMZ metasediments (H-J. Schäfer, unpublished data, B. Ordoñez-Casado, unpublished data) and adds further evidence for the 
contribution of Precambrian recycled continental crust to the European Hercynides (Gebauer et al. 1989).

The typical magmatic character of zircon 9.1 and the presence of a cluster of Cadomian-type ages at ca. $540 \mathrm{Ma}$ (analyses 1.2, 4.1, 8.1 and 9.1) suggest that the emplacement of the magmatic precursors of the Alcáçovas orthogneiss could have taken place during the Cadomian orogenic event. However, the occurrence of a second group of ages at around 460 Ma (spots 1.1, 1.3, 3.1 and 7.1) can also be interpreted as reflecting the age of protolith formation.

Unfortunately, the available geochronological data do not provide an unequivocal age for the intrusion of the Alcáçovas monzogranites. At first sight, the calc-alkaline affinities displayed by these rocks would tend to favor their magmatic crystallization occurring during the Cadomian orogeny. This hypothesis fits well with the Late PrecambrianLower Cambrian date ( $c$. 520-530 Ma) reported by Eguíluz et al. (1996) for subduction-related calcalkaline volcanic suites from the Malcocinado formation and Bodonal-Cala complex (OMZ). On the other hand, the SHRIMP $460 \mathrm{Ma}$ age is concordant within analytical error with the $\mathrm{Rb}-\mathrm{Sr}$ whole rock isochron age obtained by Priem at al. (1986) and could equally be taken as an estimate of the age of the intrusive event. If this interpretation is correct, zircons 2.1, 4.1, 5.1, 8.1 and 9.1 should be regarded as inherited crystals of a pre-existing basement. However, the Ordovician anorogenic geodynamic scenario postulated by many authors for the Iberian Variscides is not easily reconciled with the geochemical signature of the Alcáçovas monzogranites.

Because of the above arguments, the $540 \mathrm{Ma}$ age is interpreted here as the best approximate of the intrusion of the Alcáçovas protolith, in association with the Cadomian orogenic event. If such age for the protolith of the Alcáçovas orthogneiss is accepted, the presence of a cluster of U-Pb SHRIMP ages at $c a$. $460 \mathrm{Ma}$ still needs some explanation. We suggest that such Ordovician ages may reflect the occurrence of a strong thermal episode, related to extensional tectonism, that could have induced partial remelting of the material, with the consequent formation of migmatitic structures and crystallization of newly formed zircons.

Finally, the $370 \mathrm{Ma}$ age obtained in four spots from three zircon grains records the early Variscan metamorphic overprint. This is particularly clear in the spots 10.1 and 11.1 , which were placed in overgrowth rims of zircon crystals which appear bright and colorless in the CL images. In a different zircon crystal with magmatic appearance (analyses 6.1 and 6.2), a metamorphically-induced $\mathrm{U}-\mathrm{Pb}$ disturbance is indicated by the presence of $\mathrm{Pb}$-loss domains yielding young ${ }^{206} \mathrm{~Pb} /{ }^{238} \mathrm{U}$ ages and low $\mathrm{Th} / \mathrm{U}$ ratios (< 0.04). The $370 \mathrm{Ma}$ U-Pb SHRIMP age is in agreement with the ca. 375 Ma date proposed by Priem et al. (1986) for the deformation of the Alcáçovas monzogranites.

Given the extremely complex age pattern of the Alcáçovas orthogneiss, further geochemical and geochronological studies are required to get a better understanding of its tectonomagmatic evolution.

\section{CONCLUSIONS}

The new geochemical and SHRIMP U-Pb zircon data for the Portalegre and Alcáçovas orthogneisses document a complex and old history for the Iberian basement in the OMZ. Despite the controversial interpretation of the available geochronological results, a few concluding comments can be given:

a) recycling from a Precambrian continental crust with an age around 2.5 Ga (PaleoproterozoicArchean) is indicated by the detection of an inherited zircon component in the Alcáçovas orthogneisses;

b) the assumption of an intrusion age of $c a .540$ Ma for the protholith of the Alcáçovas orthogneiss is consistent with the development of an active continental margin setting in the OMZ at the end of the Proterozoic and supports the Gondwana provenance of the Iberian crust (see Fernández-Suarez et al. 2002); 
c) the Ordovician emplacement age obtained for the magmatic precursors of the Portalegre syenogranite orthogneisses $(497 \pm 10 \mathrm{Ma})$ is in reasonable agreement with the age postulated for rift-related alkaline and peralkaline magmatic activity in the OMZ (Lower Ordovician, about $480 \mathrm{Ma}$ ). Given the highly evolved character of the Portalegre orthogneisses, the Ordovician tectonic setting cannot be unambiguously constrained. These rocks may derive from crustally contaminated A-type magmas, but their geochemical signature is not incompatible with an orogenic geodynamic scenario;

d) the presence of a cluster of U-Pb SHRIMP ages at $c a .460 \mathrm{Ma}$ in the Alcáçovas orthogneisses is believed to result from post-intrusive $\mathrm{U}-\mathrm{Pb}$ zircon disturbance, possibly induced by a thermal episode occurred during Ordovician times and related to a rift-type tectonic setting. It is possible that this $460 \mathrm{Ma}$ event could be a late expression of the same extensional activity that affected the OMZ about 20 Ma earlier.

e) finally, an early Variscan metamorphic overprinting of Upper Devonian age (at $c a$. 370 Ma) is distinctly recorded by some zircon grains from the Alcáçovas orthogneisses.

\section{ACKNOWLEDGMENTS}

This work received support from the Convênio de Cooperação between the Instituto para a Cooperação Científica e Tecnológica Internacional (ICCTI Ministério da Ciência e da Tecnologia, Portugal) and the Conselho Nacional de Desenvolvimento Científico e Tecnológico (CNPq - Ministério da Ciência e Tecnologia do Brasil) that the Brazilian and Portuguese authors wish to acknowledge. The suggestions received from three anonymous reviewers have greatly improved the first version of this paper, and their help is highly acknowledged. This study is a contribution to the research Project MODELIB (POCTI/35630) CTA2000-FEDER.

\section{RESUMO}

Novas datações pelo método U-Pb SHRIMP em zircão, em dois ortognáisses de Portugal, revelam uma história geológica pré-Varística complexa para o embasamento da Zona Tectônica de Ossa-Morena da Península Ibérica. Os dados geoquímicos e geocronológicos do ortognáisse de Alcáçovas (ca. $540 \mathrm{Ma}$ ) indicam que a cristalização magmática do seu protólito deve ter ocorrido durante o evento orogênico Cadomiano. Isto é consistente com o desenvolvimento de uma margem continental ativa no final do Proterozóico, e sugere uma proveniência gondwânica para a crosta ibérica. Por outro lado, a época de colocação ordoviciana obtida para o precursor magmático do ortognáisse de Portalegre (497 \pm 10 Ma) está em razoável concordância com a idade atribuída para a atividade magmática alcalina de tipo extensional, ocorrida durante o paleozóico inferior na Zona de Ossa-Morena.

Palavras-chave: orogênico Cadomiano, geocronologia $\mathrm{U}-\mathrm{Pb}$, Maciço Ibérico, Zona de Ossa-Morena.

\section{REFERENCES}

ÁBAlos B AND Eguíluz L. 1992. El corredor blastomilonítico de Badajóz-Cordoba: de la subduccióncolisión cadomiense a la transpresión hercínica. In: Conferencia Internacional sobre el Paleozoico Inferior de Ibero-América/VIII Reunión del Grupo de Ossa-Morena. Guía de Campo de la excursión 1: 170.

Ábalos B, Gil IbARguchi JI AND Eguíluz L. 1993. A reply to "Cadomian subduction/collision and Variscan transpression in the Badajóz-Cordoba Shear Belt, southwest Spain: a discussion on the age of the main tectonometamorphic events", by Azor A, González Lodeiro F and Simancas JF. Tectonophysics 217: 347-353.

Abranches MCB, Canilho MH and Canêlhas MGS. 1979. Idade absoluta pelo método do $\mathrm{Rb}-\mathrm{Sr}$ dos granitos do Porto e de Portalegre (Nota preliminar). Boletim Soc Geol Portugal XXI: 239-248.

ANDRADE AAS. 1974. Sur l'âge des orthogneisses d'Alcáçovas (Alentejo) et des filons (basiques et acides) qui les recoupent. Memórias e Notícias. Publ Mus Lab Mineral Geol Univ Coimbra 78: 29-36.

Apalategui O, Eguíluz L and Quesada C. 1990. Ossa-Morena Zone: structure. In: DALLMEYER RD 
And Martínez García E (Eds), Pre-Mesozoic Geology of Iberia. Springer, Berlin Heidelberg, p. 280-291.

BANDRÉS A, ORdoÑEZ B, Eguíluz L AND CARRACEDO M. 1999. El complejo ígneo de Valle de La Serena: características y significado geodinámico. Geogaceta 25: 31-34.

BAndrés A, Eguíluz L And Apraiz A. 2000. El granito Precambrico de Valsequillo (zona de OssaMorena, Macizo Iberico, España). Geogaceta 28: 11-14.

Bea F, Carnicero A, Gonzalo JC, López Plaza M AND Rodríguez Alonso MD (Eds). 1987. Geologia de los granitoides y rocas asociadas del Macizo Hespérico. Editorial Rueda, Madrid.

Bellon H, Blachère H, Crousilles M, Deloche C, Dixsaut C, Hertrich B, Prost-Dame V, Rossi P, Simon D And TAMAIN G. 1979. Radiochronologie, évolution tectono-magmatique et implications métallogéniques dans les CadomoVariscides du Sud-Est Hespérique. Bull Soc Géol France 21: 113-120.

BLATRIX P AND BURG JP. 1981. ${ }^{40} \mathrm{Ar}^{-}{ }^{39}$ Ar dates from the Sierra Morena (Southern Spain): Variscan metamorphism and Cadomian Orogeny. N Jb Mineral Mth 10: 470-478.

BoogARD MVD. 1972. Conodont faunas from Portugal and Southwestern Spain. Part I. A Middle Devonian fauna from near Montemor-o-Novo. Scripta Geol 13: $1-11$.

BoogARD MVD. 1983. Conodont faunas from Portugal and Southwestern Spain. Part 7. A Frasnian fauna near the estação de Cabrela (Portugal). Scripta Geol 69: $1-18$.

Burg JP, Iglesias M, Laurent P, Matte P and RIBEIRO A. 1981. Variscan intracontinental deformation: the Coimbra-Córdoba shear zone (SW Iberian Peninsula). Tectonophysics 78: 161-177.

Castro A et Al. 2002. Paleozoic Magmatism. In: Gibbon W And Moreno T (Eds), Geology of Spain, Geological Society London, p. 117-153.

Chacón J, Oliveira V, Ribeiro A ANd Oliveira JT. 1983. La estructura de la Zona de Ossa-Morena. In: CombA JA (Coord), Livro Jubilar JM Rios. Tomo I. Instituto Geologico y Minero de Espana, Madrid, p. 490-504.
Chaminé Hi, Gama Pereira lC, Fonseca Pe, Noronha F ANd Lemos de Sousa MJ. 2003. Tectonoestratigrafia da faixa de cisalhamento de Porto - Albergaria-a-Velha - Coimbra - Tomar, entre as Zonas Centro-Ibérica e Ossa-Morena (Maciço Ibérico, W de Portugal). Cadernos Laboratorio Xeologia Laxe 28: 37-78.

Collins WJ, Beams SW, White AJR and ChapPELL BW. 1982. Nature and origin of A-type granites with particular reference to southeastern Australia. Contrib Mineral Petrol 80: 189-200.

Compston W, Williams IS And Meyer C. 1984. $\mathrm{U}-\mathrm{Pb}$ geochronology of zircons from lunar breccia 73217 using a sensitive high mass-resolution ion microprobe. J Geophys Res 89B: 525-534.

Crowley QG, Floyd PD, Winchester JA, FranKE AND HoLlAnd JG. 2000. Early Palaeozoic rirftrelated magmatism in Variscan Europe: fragmentation of the Armorican Terrane Assemblage. Terra Nova 12: 171-180.

DALlMEYER RD AND MARTÍnEZ-GARCIA E (Eds). 1990. Pre-Mesozoic geology of Iberia. Springer Verlag, Berlin-Heidelberg.

DAllmeyer RD AND Quesada C. 1992. Cadomian vs. Variscan evolution of the Ossa-Morena Zone (SW Iberia): field and ${ }^{40} \mathrm{Ar}-{ }^{39} \mathrm{Ar}$ mineral age constraints. Tectonophysics 222: 177-194.

Díaz Azpiroz M, Fernández C and Castro A. 2002. El evento de fusión parcial en el dominio continental de la banda metamórfica de Aracena (Macizo Ibérico meridional: condicionantes estructurales, geoquímicos e isotópicos. Revista Soc Geol España 15: 27-39.

Dunning GR, Diez Montes A, Matas J, Martín PARRA LM, Almarza J AND DONAIRE M. 2002. Geocronologia U/Pb del volcanismo ácido y granitoides de la Faja Pirítica Ibérica (Zona Surportuguesa). Geogaceta 32: 127-130.

Eguíluz L, Apraiz A And Ábalos B. 1996. Metamorfismo cadomiense en el sector español de la Zona de Ossa-Morena. In: ArAújo AA AND PEREIRA MF (Eds), Estudos sobre a geologia da Zona de OssaMorena (Maciço Ibérico). Univ Évora, Évora, p. 91118.

FERnÁndeZ-SuÁrez J, Gutiérrez Alonso G AND JEFFERIES T. 2002. The importance of along-margin 
terrane transport in northern Gondwana: insights from detrital zircon parentage in Neoproterozoic rocks from Iberia and Brittany. Earth Planet Sci Lett 204: 75-88.

Fonseca Pe, Munhá J, Pedro J, Rosas F, Moita P, ARAújo A AND LEAL N. 1999. Variscan ophiolites and high-pressure metamorphism in southern Iberia. Ofioliti 24: 259-268.

Galindo C, Portugal Ferreira M, Casquet C AND PRIEM HNA. 1990. Dataciones $\mathrm{Rb} / \mathrm{Sr}$ en el complejo plutónico Táliga-Barcarrota (CPTB) (Badajóz). Geogaceta 8: 7-10.

Garcia CASquero JL, BoelriJK NAIM, Chacón J AND PRIEM HNA. 1985. Rb-Sr evidence for the presence of Ordovician granites in the deformed basement of the Badajóz-Cordoba belt, SW Spain. Geol Rundsc 74: 379-384.

Gebauer D, Williams IS, Compston W AND GRUNENFELDER M. 1989. The development of the Central European continental crust since the Early Archean based on conventional and ion microprobe dating of up to 3.84 by old detrital zircons. Tectonophysics 157: 81-96.

Gibions W And Moreno T (Eds). 2002. Geology of Spain; Geological Society of London.

GonZÁlez MenÉndez L. 2002. Petrología del batolito granítico de Nisa-Albuquerque. Revista Soc Geol España 15: 233-246.

Julivert M, Fontboté JM, Ribeiro A AND CONDE LN. 1974. Memória Explicativa del Mapa Tectónico de la Península Ibérica y Baleares (E. 1:1000 000). Inst Geol Min España, p. 1-113.

Kalsbeek F And Nutman AP. 1996. Anatomy of the Early Proterozoic Nagssugtoquidian orogen, West Greenland, explored by reconnaissance SHRIMP U-Pb zircon dating. Geology 24: 515-518.

LANCELOT JR AND AllegReT A. 1982. Radiochronologie U-Pb de l'orthogneisse alcalin de Pedroso (Alto Alentejo, Portugal) et évolution anté-hercynienne de l'Europe Occidental. N Jb Mineral Mth 9: 385-394.

Lotze F. 1945. Zur Gliederung der Varisziden der Iberischen Meseta. Geotektonische Forschungen 6: $78-82$.

Mata J And Munhá J. 1985. Geochemistry of mafic metavolcanic rocks from the Estremoz region (South Central Portugal). Comun Serv Geol Portugal 71: $175-185$.
Mata J And Munhá J. 1990. Magmatogénese de metavulcanitos câmbricos do Nordeste Alentejano: os estádios iniciais de "rifting" continental. Comun Serv Geol Portugal 76: 61-89.

Mata J, Ribeiro ML and PiçARra JM. 1999. Geochemical characteristics of the S. Marcos do Campo volcanic complex (Ossa-Morena Zone): evidence for subduction-related magmatism. Comun Serv Geol Portugal 86: 3-14.

Noronha F AND Leterrier J. 2000. Complexo metamórfico da Foz do Douro (Porto). Geoquímica e geocronologia. Rev Real Academia Galega Ciencias 19: $21-42$.

Oliveira DPS, Poujol M AND RobB LJ. 2002a. U$\mathrm{Pb}$ geochronology for the Barreiros tectonised granitoids and Arronches migmatitic gneisses: Tomar Cordoba shear zone, east central Portugal. Revista Soc Geol España 15: 105-112.

Oliveira DPS, Poujol M AND RobB LJ. 2002b. A reply to discussion on " $\mathrm{U}-\mathrm{Pb}$ geochronology for the Barreiros tectonised granitoids and Arronches migmatitic gneisses: Tomar Cordoba shear zone, east central Portugal". Revista Soc Geol España 15: 253255 .

Oliveira JT, Pereira E, Ramalho M, Antunes MT AND Monteiro JH (Coord). 1992. Carta Geológica de Portugal, escala 1:500 000. Serviços Geológicos de Portugal, Lisboa.

Pereira LCG ANd Macedo CAR. 1983. Sobre a idade dos granitos de Figueiró dos Vinhos, Pedrógão Grande e dum pegmatito do Casal do Zote (Dornes) no sector da sutura Ossa-Morena - Zona Centro Ibérica, a norte de Tomar (Portugal Central); algumas implicações geotectónicas. Comun Serv Geol Portugal LXIX: 265-266.

Pereira MF AND Silva JB. 2002. Discussion on the "U-Pb geochronology for the Barreiros tectonised granitoids and Arronches migmatitic gneisses: Tomar Cordoba shear zone, east central Portugal" by de Oliveira DPS, Poujol M and Robb LJ. Rev Soc Geol España 15: 247-252.

PINTO MS. 1980/81. Geochemistry of a gnaissic quartzdiorite from Sever do Vouga (Aveiro, Northern Portugal). Bol Soc Geol Portugal XXII: 121-124.

PINTO MS. 1984. Granitóides caledónicos e hercínicos na Zona de Ossa-Morena (Portugal) - nota sobre as- 
pectos geocronológicos. Memórias e Notícias, Publ Mus Lab Mineral Geol Univ Coimbra 97: 81-94.

Pinto MS, Casquet C, Ibarrola E, Corretgé ANd Portugal Ferreira M. 1987. Síntese geocronológica dos granitóides do Maciço Hespérico. In: BeA F, CARNicero A, GONZALO JC, LÓPEZ Plaza M AND Rodríguez Alonso MD (Eds), Geologia de los granitoides y rocas asociadas del Macizo Hespérico. Editorial Rueda, Madrid, p. 69-85.

Priem HNA, BOELRIJK NAIM, VERSChURE RH, Hebeda EH ANd Verdurmen EAT. 1970. Dating events of acid plutonism through the Paleozoic of the Western Iberian Peninsula. Eclogae Geol Helv 63: 255-274.

PrIEM HNA, BOELRIJK NAIM, HEBEDA EH AND SCHERMERHORN LJG. 1986. Isotopic ages of the Alcáçovas orthogneiss and the Beja porphyries, South Portugal. Comun Serv Geol Portugal 72: 3-7.

QuesadA C. 1990. Precambrian sucessions in SW Iberia: their relationship to "Cadomian" orogenic events. In: D'Lemos RS, STRACHAN RA AND TOPlEy CG (Eds), The Cadomian Orogeny. Geol Soc Special Publication 51: 353-362.

QuesadA C. 1991. Geological constraints on the Paleozoic tectonic evolution of tectonostratigraphic terranes in the Iberian Massif. Tectonophysics 185: 225-245.

Quesada C And Munhá J. 1990. Ossa-Morena Zone: metamorphism. In: DALLMEYER RD AND MARTÍNEZ GARcía E (Eds), Pre-Mesozoic Geology of Iberia. Springer Verlag, Berlin-Heidelberg, p. 314320.

Ribeiro A, QuesAdA C AND DALlMEYER RD. 1990. Geodynamic evolution of the Iberian Massif. In: DALLMEYER RD AND MARTínez GARCíA E (Eds), Pre-Mesozoic Geology of Iberia. Springer, Berlin Heidelberg, p. 399-409.

SÁnchez-CARretero R, Eguíluz L, Pascual E AND CARRACEDO M. 1990. Igneous rocks of the Ossa-Morena Zone. In: DALlmEYER RD AND Martínez García E (Eds), Pre-Mesozoic Geology of Iberia. Springer, Berlin Heidelberg, p. 292313.

SÁnCHEZ-CARretero R, CARraCEdo M, Eguíluz L And Alonso Olazabal A. 1999. Magmatismo alcalino tardicadomiense en la Zona de Ossa
Morena (Macizo Ibérico): cartografia, petrografia y geoquímica preliminar del Macizo de Almendral. Geogaceta 26: 87-90.

SÁnChEZ FABIÁn JA. 2000. Contribución al estudio y caracterización de los granitoides de la antiforma de Olivenza - Monastério. Studia Geologica Salmanticensia 36: 85-107.

Santos JF, Mata J, Gonçalves F and Munhá J. 1987. Contribuição para o conhecimento geológicopetrológico da região de Santa Susana: o complexo vulcano-sedimentar da Toca da Moura. Comun Serv Geol Portugal 73: 29-48.

SCHÄFER H-J, GEBAUER D, NÄGLER TH.F AND QUADT A VON. 1988. U-Pb zircon and Sm-Nd studies of various rock-types of the Ossa-Morena Zone (Southwest Spain). In: Simposio sobre Cinturones orogénicos, Sociedad Geologica de España, I Congreso Esp Geologia, p. 51-57.

SCHÄFER H-J, NÄGLER TH.F AND GEBAUER D. 1999. Pan-African and Caledonian ages in the Ossa-Morena Zone (Southwest Spain): a U-Pb zircon and Sm-Nd study. Terra Abstr 1: 350-351.

Steiger RH AND JAGER E. 1977. Subcomission on geochronology: convention for the use of decay constants in geo- and cosmochronology. Earth Planet Sci Lett 36: 359-362.

STERN RA. 1998. High-resolution SIMS determination of radiogenic trace-isotope ratios in minerals. In: CABri LJ And VAughan DJ (Eds), Modern approaches to ore and environmental mineralogy. Mineralogical Association of Canada. Short course series 27: 241-268.

Sun S AND MCDonough WF. 1989. Chemical and isotopic systematics of oceanic basalts: implications for mantle composition and processes. In: SAUNDERS AD AND NORRY MJ (Eds), Magmatism in the Ocean Basins. Geol Soc Special Publication 42: 313-345.

TeIXEIRA C. 1976. Acerca da idade das rochas graníticas portuguesas. Boletim Soc Geol Portugal 20: 131161.

VAlladares MI, BARba P AND Ugidos JM. 2002. Precambrian. In: GIBBON W AND MORENO T (Eds), Geology of Spain, Geological Society London, p. 117-153. 
VAlverde-VAquero P AND Dunning GR. 2000. New U-Pb ages for Early Ordovician magmatism in Central Spain. J Geol Soc London 157: 15-26.

Whalen JB, Currie KL and Chappell BW. 1987. A-type granites: geochemical characteristics, discrimination and petrogenesis. Contrib Mineral Petrol 95: 407-419.

WILKINSON DR, BAILEY DK, HALSALL TJ AND QUAIFE PA. 1984. Geochemical variations in granitoid magmatism, Central Portugal. Memórias e Notícias. Publ Mus Lab Mineral Geol Univ Coimbra 98: 305-319.
WILLIAMS IS. 1998. U-Th-Pb geochronology by ion microprobe. In: MCKIBBEN MA, SHANKS III WCP AND RIDLEY WI (Eds), Applications of microanalytical techniques to understanding mineralizing processes. Society of Economic Geologists. Short course 7. 